\title{
Principles and Standards for Surveying a College Library'
}

\author{
Peyton Hurt is librarian at \\ Williams College.
}

\begin{abstract}
A COLLEGE LIBRARY SURVEY is a careful, critical analysis of the condition of the library of a particular college. It gives due regard to the library's aims, objectives, and needs, and may outline a statement of plans for future development. In practice, such a survey is often a longneeded thorough inquiry into the condition of a weak library, with the double purpose of deciding on needed improvements and stimulating the necessary interest and aid to enliven the library's future. But a systematic survey may be more useful to a good library than to a poor one, for nearly anyone can point out important weaknesses in a poor library, while only a careful study will show faults in a good one. And at the same time, the poorer institutions are usually confined to limited library service by financial considerations, whereas the colleges with better libraries sometimes have funds enough to permit costly mistakes in extensive library development. Even the smallest colleges seem able to venture into strange paths, often in vain attempts to imitate larger colleges, or even universities, in the provision of 1 The material of this article was developed for
later inclusion in a projected manual on "Surveying the College Library." It is based on a paper read at the Twenty-eighth Annual Conference of Eastern College Librarians at Columbia University. November $23,1940$.
\end{abstract}

library services. Consequently, any college interested in guaranteeing full coordination of library services with its educational program may employ the library survey to good advantage. In fact, wise administration should call for frequent study and analysis of college library functions, to give greater vitality to that often avowed "heart of the college."

\section{Definition of a College Library}

In order to survey a college library and plan its future development we should first define the library and establish its proper place in the college. The library should operate as an integral part of the whole college, deriving significance from its functions in the larger institution which it serves. It should be defined as a dynamic institution, comprising books, physical plant, and staff, organized and functioning in the college program. The college library is not merely the books, the building, and the staff, ready and waiting to serve the students and faculty upon demand. The use of the library, the services which it performs, are definitely part of the institution itself. The library is thus a going concern, alive and participating in the college educational process. In surveying the library, one should go further and define it as including the attitude of the president, faculty, and students toward library facilities, use, and problems. 
The college library is therefore to be surveyed as an active institution, including the library building, the book collection, the staff, the organization, arrangement, and distribution of these facilities, the attitude of the president, faculty, and students toward it, and its use by students and faculty in their collegiate activities. In short the college library is to be evaluated by how its organized facilities operate as a college department. It must be considered with due emphasis on those characteristics which make it dynamic, active, and functioning within the whole college organization.

In order to show the validity of the characteristics included in the definition above, we may formulate a brief descriptive statement of a hypothetical institution. One might thus speak of $\mathbf{X}$ College as having a large book collection, rich in basic source materials, but lean in current books and items for college courses, a scholarly staff devoted to the development of research materials but una are of the important current book needs of the college program, or unsympathetic with such needs, a building designed primarily for architectural qualities, which with related memorial features har . distorted normal distribution of books and prevented efficient and economical arrangement of library services, and a president and faculty who, though critical of library inefficiencies, were apparently satisfied with an instructional program which did not result in extensive student reading as evidenced by library use.

If we break the definition into its various component parts, we may readily see that, by limitation of the points covered, the value of the description is greatly curtailed. It is not enough, for example, to say that $\mathbf{X}$ College Library has a large book collection, rich in basic source materials, housed in a luxurious building, and managed by a staff with deep scholarly interests. The sacrifice of functional aims to "aesthetic" architectural considerations, which appears to be a curse of college library buildings, the failure of the faculty and staff to stimulate student use of the library, and the lack of current material for class use, more than offset the good features of this library, especially if it is to be judged by its contribution to the college educational program.

\section{Data for the College Library Survey}

The techniques of investigating library problems are developing rapidly. Data on college libraries are regularly collected, analyzed, and appraised for their meaning and significance. Compiled statistics of college and university libraries are published each year. Various features of college libraries have been critically analyzed and standards for some phases of library service have become fairly well established. Other problems of library organization and practice are currently being explored and mapped for the guidance of all interested in college library development. The results furnish us a body of data and indicate methods of surveying a college library with a fair certainty of reaching an accurate diagnosis of its condition and needs. From such a survey, it is no doubt possible to prescribe reasonably sure cures for college library ailments. .

It is nevertheless easier to survey and measure various individual features of a college library than to determine what their measurement means. The question is not so much how to survey a college library as what to survey and how properly to evaluate the results. Continued research in library science will develop 
additional means of collecting significant data and more exact tests for evaluating statistics of various kinds. But the collection of statistics and other factual data will never in itself constitute an appraisal of a college library. One must go beyond statistical data and consider other factors. We may measure all tangible things and still be lacking in material for a sound diagnosis of the significance and value of the services of a particular library. For there are some unmeasurable conditions which are the decisive elements in library service. This is not to say that the factors usually considered and the statistics regularly counted are unimportant. It is rather that there are some major factors with implications not so readily counted, and some unmeasurable conditions essential to the evaluation of library facilities, organization, and practice. For example: How shall we measure library use? It is one of the somewhat intangible factors of greatest importance. Statistics of book circulation and library attendance records will measure roughly the quantity of library use. But if we ask, use for what and to what avail, they furnish no answer. We must consider factors which for the present cannot be reduced to statistical data.

In the last analysis, the whole library survey must depend upon the exercise of sound judgment. This judgment, that is, expert opinion, must analyze, evaluate, and interpret statistical data and other objective measurements. It must also take into account those factors which cannot be reduced to statistics or otherwise measured in quantity. In this appraisal a systematic approach will limit and direct the exercise of judgment and the use of expert opinion, so that we may be sure to find the true meaning of facts, figures, and observations collected in the course of a library survey.

\section{Standards for College Libraries}

Good standards of measurement and sound principles of judgment will introduce into a library survey some of the qualities of scientific observation and evaluation. Standards are needed to give perspective to the consideration of data about a library. Principles of judgment are needed to furnish a point of view, to guarantee careful and critical consideration of all pertinent factors on some established basis, or in a stated frame of reference.

Most college library standards are based on comparisons. Such standards arise from the collection and publication of annual library statistics and from special studies and surveys for which data are collected and made public. By these statistics, one institution may be compared with another or with all others. Standards are set as better than the lowest ranking colleges, equal to the average, or in the upper ranks.

Even expert opinion is based largely upon comparative standards; which is to say that the expert will compare features of a given library with what his experience and special training tell him to be the standard for any similar library in the same situation. The expert will go further, of course, and deduce standards by considering all relevant factors in the light of his own experience and insight into library organization and practice. Thus a college library survey may create standards against which to measure particular features of the library under observation.

Comparative findings soon tend to be converted into more or less exact state- 
ments of standards for individual features of college library organization and practice. So library literature is fairly definite on matters such as how much money a college library should expend per student, on the percentage of funds to be spent for books and for staff, on the proportion of the students to be provided with seating space in the reading rooms, and even on the number of books likely to be borrowed per student for home use. Likewise, we have check lists of reference books, of periodicals, and of best books, as well as pay-plans, and manuals of service prepared by college library experts. Sponsored by college accrediting agencies and by librarians' professional associations, these are the fruit of comparative data and of expert opinion, designed to stimulate and aid college library surveys.

But in the final analysis, each institution must be judged by how well it performs the services required to meet the needs of its own particular college. For this, each institution must somehow create its own standards, and we should rely most heavily upon these individual standards in any survey to determine the quality of the facilities, organization, and services of a particular library.

\section{Principles for Appraising College Library Functions}

The formulation of standards for a college library and the appraisal of statistics, observations, and comparative data regarding it call for some underlying principles of judgment. Comparison with other libraries, as discussed in preceding pages, is a much-used measure against which to consider the adequacy of the book collection, staff, library funds, and other items in library organization and practice. As a principle of judgment, the use of these check lists and measuring rods ranks high in convenience and effectiveness in demonstrating the relative inadequacy of poorer institutions. Such yardsticks may not be reliable for better college libraries, however, where there may be sharp variation from the average, or standard, without any failure to meet effectively the requirements of library service arising from the college educational program.

A basic principle, as stated above, should be to measure each college library by its own objectives. These objectives should first be scrutinized and evaluated in the light of the college's individual educational program, and then their accomplishment may be taken as a fair test of the library's efficiency as a college department. The nature of the college program is the determining factor in the functions of the library. Any limitation of the college educational activities, special emphasis on particular phases of the curriculum, or variation for the college as a whole, should necessarily set limits to the main lines of library development.

Some statement of the aims and objectives of the whole college is therefore of first importance to a library survey. This statement should draw a clear distinction between the liberal arts college, with its teaching program, and the university, with its graduate study, emphasis on research, and various professional schools. Many college libraries suffer from failure on the part of the controlling authorities to distinguish between the proper extent and nature of the contents and services of a college library, a university library, and a research library. Presidents, librarians, and faculties should be careful to avoid thinking of the college library in terms of their own experience with the university 
library for graduate study or other university work.

\section{Financial Limitations a Factor}

Consideration of the financial limitations of a college should be a fundamental factor in setting standards for its library. Only a few colleges can afford to try to imitate universities in the collection of research materials and the provision of elaborate library facilities not needed for the college teaching program. Even these should consider how such enlarged services might interfere with the main objectives of college library service. The cost of the library service is a main consideration even when it is clearly within the college's ability to pay. But consideration of cost should be balanced by equal consideration of value received. Library costs should be compared sometimes with costs of other college functions. The annual cost of books and library service in a given field, for example, may seem trifling if compared with the total salaries paid to instructors in that field, even with due regard to their respective contributions to the college program. The balancing of cost against real value received should prevent the false economy of curtailment of essential library expenditures. At the same time, it should eliminate some unnecessary but costly features which are apt to creep unnoticed into college library practice, and then be continued for years through habit or through mistaken notions of their significance to college functions. Some luxuries may be worth the cost, but a college library survey must question both cost and value received in the appraisal of library services.

One must consider the size and character of the student body in setting standards for library service. As an obvious exam- ple, the large college in a metropolitan area, with a mixed student body, many of them non-resident, has problems of library service quite different from those of a college situated in a small village and having a limited and homogeneous group of students. More subtle differences in student attitudes, living conditions, and general campus life may be the basis for significant distinctions in library organization and practice.

The degree of integration of one feature of college library organization and practice with others and with all related activities of the whole college is a point for serious consideration. Needless subdivision of functions is costly and productive of unprofitable specialization of effort. Lack of unification, of coordination, of cooperation, or of integration may sometimes be a serious fault in library services which at first sight seem to be efficient units of the college organization.

The attitude of the president and faculty toward the library is also an important point to consider in gauging the suitability of library services. If extensive library use is not wanted, library standards should be set accordingly, making some allowance, of course, for the influence good library service may have in leading the faculty to make more use of the library for collegiate work.

\section{Counterbalance Expert Opinion}

Expert opinion should play a part in any survey to evaluate library facilities, organization, or practice. It is desirable, however, to counterbalance the opinion of the expert, based on intimate knowledge of technical detail, with the untrammelled and often broader vision of interested scholars without training or experience in library practice. But too often laymen 
can only "discover" what is common knowledge to experienced librarians. On the other hand, failure to give due consideration to expert opinion on library problems may result in failure to recognize practical restrictions to the development of well-meant but unmanageable programs for library development.

College teaching methods are a sound guide for determining library objectives, and for measuring the need for different kinds of library service. Teaching methods have for years past been changing in the direction of requiring wider collateral reading and less dependence on a single text. But this change is not nearly so widespread or so fully accepted as many would assume. In any case, a careful analysis of teaching methods and consequent library use in a particular college is a much better basis for planning library service than a general assumption on this point.

The degree of independent study and extracurricular reading should help determine college library standards almost as much as the closely related matter of teaching methods. Honors courses usually require wider reading and more independent library use. Most student extracurricular reading is likely to be an outgrowth of good teaching and of interesting courses of study. Ideally it should be so, but such reading may be stimulated by the library itself, through arrangement of the book collection and display of selected material so as to attract student and faculty attention and arouse interest.

\section{Faculty Research a Factor}

The extent and nature of faculty research is another extracurricular factor to be considered in determining college library policy and practice. If, as has been recommended, the college does not attempt to be a university, its library may well set limits to the amount of research materials to be collected and preserved for faculty use. The development of a good reference collection, the use of microfilm, of interlibrary loan, and perhaps a college policy of granting funds for travel and research, should be considered as alternatives to attempts at actually supplying research library materials and service. Here, as in other factors affecting the library, there is need to formulate definite college policies which will serve to guide library development.

Not all of the principles affecting judgment of the library are based on library use arising from the college program. To a certain extent the college library is an end in itself, and can exert a powerful influence on the development of the college. The degree of library influence in the college program is a matter for considerable thought in a library survey. This involves the position and prestige of the librarian and his staff in the college community, and also the extent to which the library controls or shapes the educational process.

It is unwise for the college library to try to be too much of an end in itself. But there is clearly a responsibility for it to be something of a depository of books on all subjects, a storehouse of learning for the academic community, and the basis for study and teaching of topics not immediately covered by the curriculum. The library has also an obligation to lead the college in the field of books. The history of printing, fine books, rare books-these are fields in which the library has some inherent responsibility. To preserve and exhibit occasionally materials of this kind is a natural function of the college library. 
Likewise there are some fields in which special collections may properly be developed. College memorabilia and documents of local history usually must be collected by the college library if they are to be preserved at all. So also the library may be expected to provide cultural reading, books of general interest, and even purely recreational reading, just because it is the source of reading materials of all kinds for students and faculty. Finally, the library has some monumental features: it is often the institution, or building, most frequently shown to visitors to the college. In the same way, it may be a memorial building and may house some memorial collections.

But all these characteristics which tend to make the library an end in itself-from leadership in the field of books to monumental and memorial features-should be scrutinized very critically in setting standards for college library practice. These things should be examined with due regard to their significance and effect on the whole college library program. To a certain extent, the college library may have legitimate functions not directly connected with college study and teaching. But the cultivation of these extracurricular features of the library may easily become a costly luxury, interfering with more important phases of college library service. A library survey is often needed to determine what should be the main lines of library development, to distinguish the important from the unimportant, the essential from the luxurious features of college library organization and practice.

\section{Summary}

A college library survey takes into account the whole library as a dynamic institution, organized and functioning in the college educational program. Standards may be found in library literature and furthermore may be set up by comparing one library with others. But in the last analysis, a library must be judged by its own standards, based on the performance of the aims and objectives set for it by its own college program. For systematic procedure, some basic principles of judgment are essential to the formulation of standards and the evaluation of data in a library survey.

The underlying principles of judgment should be: (I) the measurement of each library mainly by its own standards; (2) the use also of comparative standards and of recognized "yardsticks"; (3) a statement of the aims and objectives of the whole college as a basis for the library program; (4) consideration of the financial limitations of the college; (5) the cost of library service balanced against value received; (6) the size and character of the student body as the basis for distinctions in library organization and practice; (7) the degree of integration of library and college functions as a measure of efficiency; (8) the attitude of the president and faculty as an influence on library plans; (9) due consideration of expert as well as lay opinion; ( IO) college teaching methods as a basis for the extent and nature of library services; (I I) independent study, honors courses, and extracurricular reading as additional factors; ( 2 2) the extent and nature of faculty research, and college policy in support of it, as a guide to library practice; (I3) the degree to which the library is to be an end in itself-as a storehouse of learning, as a leader in the field of books, as a source of general and recreational reading, and as a monumental or memorial feature of the college. 